\title{
Vaso-Occlusive Crisis
}

National Cancer Institute

\section{Source}

National Cancer Institute. Vaso-Occlusive Crisis. NCI Thesaurus. Code C122412.

An exacerbation of sickle cell disease. 